\title{
Naturalisme og kristendom: Et dogmatisk perspektiv
}

\author{
Lektor, ph.d. \\ Johanne Stubbe Teglbjarg Kristensen
}

\begin{abstract}
Against the temptation to seek a complete conceptual clarification of the relationship between Naturalism and Christianity, this article argues from a dogmatic perspective that the relationship between Naturalism and Christianity demands an approach that takes into consideration the limits and complications of dogmatic conceptuality itself. This approach proceeds from the post-dialectical awareness of a highly dialectical relationship of the concepts of Naturalism and Christianity, which makes them impossible to synthesize dogmatically and yet, equally impossible to conceive of as irreconcilable. By moving from the post-dialectical understanding of Naturalism in relation to the notion of theology, revelation and faith to the history and appearance of the concept of Naturalism in its relation to Supernaturalism, it is argued that Naturalism and Christianity shares an ambiguous notion of human rationality, which according to post-dialectical theology is due to a deeper complication of subjectivity; this puts certain methodological demands on a theology of Naturalism.
\end{abstract}

Key words: Christianity - Naturalism - Dogmatics - Phenomenology Post-dialectical theology - Maurice Merleau-Ponty.

Det hersker ikke enighed om, hvordan forholdet mellem naturalisme og kristendom bør begribes teologisk ligesom det også diskuteres, hvorvidt det er en teologisk opgave at begribe dette forhold, og om forholdet i givet fald overhovedet bør begribes eller på anden måde formidles.

I det følgende vil jeg foreslå en måde at relatere naturalisme og kristendom på, der tager denne uenighed om forholdet mellem naturalisme og kristendom til dogmatisk efterretning som en del af den teologiske tradition selv, og således tager udgangspunkt $i$, at begreberne "naturalisme" og "kristendom" i dette perspektiv både er modsatte tilgange til tilværelsen og dog dybt forbundne perspektiver. I dogmatikken udgør forholdet mellem naturalisme og kristendom en særlig udfordring, der støder på indre dogmatisk modstand, når det begrebsliggøres og forsøges afklaret. Det betyder ikke nødvendigvis, at forholdet mellem naturalisme og kristendom ikke bør bearbejdes 
begrebsligt, eller at ethvert afklaringsforsøg nødvandigvis er misforstået, men det betyder, at begrebernes indbyrdes afhængighed stiller nogle krav til, hvordan teologien kan omgås dem. Denne udfordring vil jeg i det følgende skitsere dogmatisk i tre skridt. Jeg vil først introducere den efter-dialektiske sammenhæng, som forholdet mellem naturalisme og kristendom aktuelt diskuteres dogmatisk i. Dernæst vil jeg betragte selve begreberne "naturalisme" og "kristendom" i deres historisk-fænomenologiske sammenhæng, og endeligt vil jeg vende tilbage til den aktuelle dogmatiske udfordring og en mulig dogmatisk opfattelse af deres forhold.

\section{Den efter-dialektiske begrebssammenhæng}

I nyere tyske indføringer i den teologiske dogmatik er der trods nedarvede modsætningsforhold bred konsensus om indkredsningen af særlige temaer, som hver på deres måde udgør indgange til en mulig afklaring af forholdet mellem naturalisme og kristendom. ${ }^{1}$ Det drejer sig om forskellige indledningsorienterede eller fundamentalteologiske temaer, der også samlet set udtrykker mere overordnede kendetegn ved forholdet mellem naturalisme og kristendom, nemlig at de to tilsyneladende forskellige begreber hører tæt sammen. Lad os se på disse temaer og på den efterdialektiske sammenhæng, som naturalisme og kristendom hører hjemme i. ${ }^{2}$

\section{Teologiens eksklusivitet?}

Det første tema, der udgør en mulig indgang, er temaet teologi eller mere snævert temaet dogmatik som akademisk disciplin, hvor diskus-

1. Se Christian Danz, Einführung in die evangelische Dogmatik (Darmstadt: Wissenschaftliche Buchgesellshaft 2010), Wilfried Härle, Dogmatik (Berlin: Walter de Gruyter 1995), Dietrich Korsch, Dogmatik im Grundriss (Tübingen: Mohr Siebeck 2000), Rochus Leonhardt, Grundinformation Dogmatik (Göttingen: Vandenhoeck \& Ruprecht 2001), Gunda Schneider-Flume, Grundkurs Dogmatik (Göttingen: Vandenhoeck \& Ruprecht 2004).

2. Gunther Wenz bruger begrebet efterdialektisk teologi som (indrømmet problematisk) betegnelse for den tyske evangeliske teologi efter 1945 og beskriver den som karakteriseret ved genopdagelse og optagelse af almene spørgsmål dvs. ved "Emanzipation ethischer Theologie", "Rehistorisierung des theologischen Bewusstseins", "Neubesinnung auf die Themen der Athropologie", "Neubewertung der Religionsthematik" og et tiltagende økumenisk perspektiv (Gunther Wenz, Offenbarung. Studium Systematische Theologie. Göttingen: Vandenhoeck \& Ruprect 2005, 275-276). 
sionen om teologiens videnskabelighed traditionelt hører hjemme. ${ }^{3}$ Som en disciplin, der reflekterer over den kristne tro i dens forskellige skikkelser, udfolder teologien sig både i forhold til andre discipliner og i forhold til en bredere offentlighed, som i dag i vidt omfang er præget af en eller anden form for naturalisme. ${ }^{4}$ Idet teologien udfolder sig selv som videnskab, forholder den sig til andre opfattelser af, hvad der kendetegner videnskabelighed, og udfolder omvendt sin opfattelse af videnskab, idet den forholder sig til sig selv som videnskab. Der er i den forbindelse udbredt enighed om, at teologiens videnskabelighed indebærer, at den udfolder sig systematisk i sin helhed, metodisk klart, begrundende og kritisk, så udsagn kan efterprøves i deres sammenhæng. Der er således også enighed om, at videnskabelighed dybest set har at gøre med anbringelsen af genstande, udsagn eller forhold i deres rette sammenhæng. ${ }^{5}$

Men hvad den rette sammenhæng er, og hvordan en sådan kritisk efterprøvning af udsagn bør udfolde sig, er der ikke enighed om. På

3. Se Danz (2010, 11ff.), Härle (1995, 3ff.), Korsch (2000, 1ff.), Leonhardt (2001, 63ff.) og Schneider-Flume (2004, 33ff.).

4. Det er påfaldende, at disse fremstillinger alle indledes ganske traditionelt med videnskabelige selvdefinitioner samtidigt med, at disse selvdefinitioner - altså selvforståelsen som videnskab - hurtigt træder i baggrunden for selvforståelsen som dogmatik, hvilket trods den traditionelle indledning, primært udfoldes i sammenhængen af erfaringer fremfor i forhold til videnskabeligt reflekterede erfaringer eller andre videnskaber. Dertil kommer, at forholdet mellem denne - fænomenologisk eller hermeneutisk prægede tilgang - ikke relateres direkte til samtidens videnskab, og derfor finder man typisk heller ikke udførlige overvejelser over vores eventuelle aktuelle naturalistiske kontekst eller om synet på naturalisme som sådan. Se f.eks. Korsch (2000, 1ff., 14ff.), der dog stiller naturalisme op overfor idealisme i forbindelse med spørgsmålet om selv- og verdensfortolkning, og Schneider-Flume (2004, 33ff.).

5. Christian Danz beskriver teologiens videnskabelighed som den dogmatiske videnskabelighed: "In der Moderne wurde auf der Grundlage der Unterscheidung von Theologie und Religion die theologische Dogmatik zu einer reflexiven Beschreibung der christlichen Religion. Aufgabe der Dogmatik ist es das materialen Wesen der Christlichen Religion in einem systematischen Zusammenhang zu entfalten und die Identität des Christentums auf eine normative Weise zu bestimmen. Die methodische Grundlage bildet die Unterscheidung von Theologie und Religion. Diese Unterscheidung ist jedoch eine solche, die in der Theologie selbst vorgenommen wird. [...] Die theologische Dogmatik wird dadurch zu einer Theorie der Religion, der die Aufgabe obliegt, die Religion im Medium der Wissenschaft zu explizieren" (Danz 2010, 22). For Danz er det således afgørende, at den dogmatiske selvbeskrivelse er systematisk og normativ og videnskabeligt formidlet. Härle ser også teologien som troens intellektuelle regnskabsaflæggelse (hvilket også implicerer systematik og normativitet), men lægger modsat Danz ikke vægt på videnskaben som teologiens medium, men ser den som teologiens instrument (Härle 1995, 15). Forskellen er markant, men modsiger ikke deres enighed om, at teologiens videnskabelighed er væsentlig. Se også Korsch (2000, 2-3), Leonhardt (2001, 70-71) og Schneider-Flume (2004, 63-64). 
den ene side indebærer dogmatiske udsagn, fordi de drejer sig om Gud, et krav om en overindividuel eller måske ligefrem universel gyldighed, og bør derfor, kan man argumentere for, efterprøves i henhold til universelle, objektive eller tredje persons kriterier, men på den anden side drejer de dogmatiske udsagn sig ikke uden videre om "Gott an sich", men om Gud i sit forhold til mennesket og for så vidt om Gud som erfaret af mennesket. Derfor er det, hvis disse udsagn skal efterprøves, ikke muligt at se bort fra menneskets erfaring som betingelse både for udsagnene og for deres efterprøvning. Det gælder både generelt, men også specifikt sådan, at den eventuelle efterprøvelse eller eftertænkning bliver udfordret af det bestemte gudsforhold og således af det konkrete menneske, der i dets tro eller vantro udfører den. Den bliver fundamentalt $o g$ konkret udfordret af førstepersonsperspektivet. Dette skærper spørgsmålet om en eventuel naturalistisk efterprøvning af kristne udsagn - og komplicerer et eventuelt spørgsmål om muligheden af en naturalisering af kristendommen. ${ }^{6}$

At et rent teoretisk perspektiv på Gud er skrøbeligt eller ligefrem umuligt, og at vi kun kender Gud gennem den konkrete erfarings formidling af perspektiver, er allerede en reformatorisk og i særdeleshed moderne erkendelse. Den indebærer, at det menneske, hvis erfaringer dogmatikken i dag må tage udgangspunkt $\mathrm{i}$, på den ene side er "mennesket" i sin abstrakte forskellighed fra Gud, og på den anden side også et konkret menneske, hvis forskel fra Gud faktisk udfolder sig negativt (som synd) og positivt (i tro). Faktisk står mennesket ikke neutralt overfor Gud. Dogmatikken skal derfor ikke blot efterprøve en teori eller et kristent begreb om Gud, som det kan forholde sig neutralt til, men udgør allerede selv en slags efterprøvning, som det nu kun kan eftertænke. Den dogmatiske identifikation af det særligt kristne fremviser således en enhed af efterprøvning og eftertænkning.

6. Danz udlægger betydningen af dette under henvisning til Luthers opfattelse af dogmatikken som troslære, dvs. som en refleksiv eller cirkulær fremstilling af den kristne tro i dens endelighed og historicitet, hvor troen selv forstås som "das Geschehen des Sich-Verstehens des Menschen” (Danz 2010, 30-31, 87-88). Rochus Leonhardt udfolder det dermed etablerede reformatoriske dilemma mellem refleksion og erfaring med henvisning til Bultmann: "[...] solche Aussagen über Gott, die 'von der konkreten Situation des Redenden' absehen, handlen nach Bultmann 'von allem andern als von Gott'. Denn weil sie vom Glauben des Redenden unabhängig sind, sind sie keine Aussagen christlicher Theologie [...] Mit dieser Ablehnung von Neutralität in der Gottesfrage wird allerdings Glaube zur Grundlage dogmatischer Argumentation erhoben" (Leonhardt 2001, 71-72). Schneider-Flume udfolder det samme forhold med henvisning til Barth, for hvem dogmatikken er en funktion af den bestemte kristne kirke i dens forhold til Gud og skriver "[D] amit weist Barth auf die zirkuläre Struktur theologischen Arbeitens im weitesten Sinne hin: Von ihren eigenen Voraussetzungen aus überprüft die Kirche die ihr eigentümlichen Rede" (Schneider-Flume 2004, 40-41, 55-56). 
Denne teologiske identifikation af det kristne kompliceres yderligere, fordi den på den ene side er menneskets, ligesom også menneskets tro netop tilhører mennesket, men på den anden side udmærker sig ved en dybere fremmedhed eller passivitet. ${ }^{7}$ Teologien selv og den Gud, den taler om, kan derfor heller ikke identificeres som noget selverfaret eller i det hele taget immanent, hvad enten dette er ens egen religion, tro eller tænkning, ligeså lidt som den omvendt kan identificeres som et rent fremmed og ydre ord. Den drejer sig ikke om en ubestemt transcendens, men tværtimod om et bestemt forhold mellem transcendens og immanens, hvis identifikation går gennem menneskets egen forvikling af de to.

På grund af teologiens indviklede forhold mellem sit eget og det fremmede, er det ikke på forhånd givet, hvad vi præcis bør forstå ved teologi som teologi og teologi som videnskab. Det er ikke på forhånd - altså teoretisk - til at vide, hvad der er særligt ved teologien og hvad der ikke er, og derfor heller ikke til at vide, hvad der er for et begreb om det kristne, vi skal relatere til naturalisme, før det allerede er gjort. Omvendt kan man heller ikke efterfølgende vide, om det nu var det rigtige begreb. Den dogmatiske tradition hjælper os altså ikke direkte, for den er ikke selv et svar på dette identifikationsproblem, men et udtryk for det. Kun som et udtryk for identifikationsproblemet, kan den indirekte bidrage til en efterprøvning og eftertænkning af den kristne erfaring af Gud. Når den dogmatiske diskussion om en videnskabelig efterprøvning af dogmatiske udsagn i dag er uafklaret, så er det altså ikke udtryk for en vilkårlig strid om, hvorvidt dogmatikken bør stilles til ansvar eller ej, men tværtimod udtryk for en udbredt enighed om, at det almene ansvar, som teologien faktisk står overfor, er indviklet at folde ud, fordi teologien slet ikke er så eksklusiv endda. Fordi den ikke bare er teologi, men også udfolder sig i modsætning til sig selv. Derfor er forholdet mellem naturalisme og kristendom ikke til at afklare teologisk på forhånd - uden om

7. Danz fører denne distinktions- og syntesekomplikation tilbage til Luthers reformation af begrebet "tro": "Glaube ist für Luther die individuelle Aneignung der Wahrheit. Erst im Christus ergreifenden Glauben wird sich der Mensch verständlich und kommt zur Wahrheit. Mit dieser Fassung des Glaubensverständnisses durch Luther ist ein Problem verbunden, welches die nachfolgende protestantische Theologie bis in die Gegenwart in Atem gehalten hat. Es besteht in der Frage, wie sich die individuelle Aneignung der Wahrheit so verstehen last, dass sie nicht selbst wieder als ein Werk des Menschen erscheint" (Danz 2010, 35). Hvordan kan en individuel tilegnelse være udtryk for Gud? Dvs. i hvilken forstand kan tilegnelsen forstås som udtryk for en passivitet og individualiteten som universalitet? 
den konkrete udfoldelse - ligesom det tilsvarende er udfordrende at begrebsliggøre efterfølgende. ${ }^{8}$

\section{Abenbaringens radikalitet?}

Dykker vi længere ned i det dogmatiske forhold mellem naturalisme og kristendom, finder vi det andet oplagte indledningstema, nemlig temaet åbenbaring, forstået som begrebet for Guds tilkendegivelse af sig selv for mennesker, og herunder tages det klassiske spørgsmål om gudserkendelse og naturlig teologi op, for i dette møder vi efterprøvnings- og eftertænkningsproblematikken i en yderligere skærpet form, nemlig i en decideret erkendelsesproblematik. Sagen er nemlig, at vi, hvis vi ikke kan efterprøve udsagn om troen uden om troen, heller ikke kan prøve dem uden om troens forudsætning, der er åbenbaringen af Gud i Jesus Kristus. ${ }^{9}$ Guds åbenbaring udgør fundamentet for troen samtidigt med, at denne åbenbaring har mennesket som

8. Bevidstheden om, at der er en grænse for den begrebslige afklaring, udtrykkes af Danz ved understregningen af teologiens forpligtelse på troen som "reflektiertes Endlichkeitsbewusstsein" og "unableitbares Geschehen", hvilket konkret indebærer en dogmatisk refleksivitet og teologisk cirkularitet. Dette betyder ikke, at han forstår teologien som en absolut eller abstrakt struktur, dvs. som udtryk for en cirkularitet, der lukker teologien om sig selv - og ophæver efterprøvningskravet - men tværtimod som et konkret foretagende, der skærper eftertænkningsproblematikken, idet refleksiviteten tvinger dogmatikken til at besinde sig på sin konkrete kontingens og sine historiske rødder (Danz 2010, 37, 41, 88). Korsch bestemmer tilsvarende, men overordnet, teologien som forpligtet af troen som en vished, der livslangt kan ledsage "das genaue Ineinander von Gottesverhältnis, Selbstverhältnis und Weltverhältnis" altså forstået som forholdet mellem gudsforholdet, der er ubetinget, og de to andre forhold, der ikke er det (Korsch 2000, 19). Denne dimension får Korsch til at bestemme troens sprog som bønnens og takkens sprog, dvs. som et sprog, der realiserer en særlig bevidsthed om sin egen grænse - sin menneskelighed og endelighed (Korsch 2000, 29-35). Schneider-Flume peger også på cirkulariteten og henviser til dogmatikkens konkrete narrative kontekst og sproglige forudsætninger som det, der hindrer den i at gå op i sig selv (Schneider-Flume 2004, 61-62, 66). Leonhardt nævner forskellige opfattelser af, hvorfor kravet om en eventuel dogmatisk efterprøvning af udsagn ikke ophæves af dogmatikkens refleksivitet, men tværtimod skærper det, og han hævder selv, at man kan skelne mellem forsvaret for en rent metodologisk efterprøvning og en mere indholdsmæssig og foretage den ene uden den anden, dvs. man kan efterprøve refleksionen over troen, men ikke troen selv, der som tillid ikke kan efterprøves (Leonhardt 2001, 72-75). Dermed møder vi igen den reformatoriske og moderne opfattelse, at troens karakter indebærer, at der er en særlig grænse for efterprøvning af dogmatikkens udsagn og dermed også for deres almene afklaring. Det moderne videnskabelige afklaringskrav hænger altså tæt sammen med opfattelsen af, at afklaringen har en grænse.

9. Se Danz (2010, 44ff.), Korsch (2000, 17) og Leonhardt (2001, 76ff). 
modtager og derfor ikke kan abstraheres fra dette, men også kun identificeres gennem menneskets tro.

Dette introducerer en dybere problematik i diskussionen om teologiens videnskabelighed, for åbenbaringen, som troen er modtagelse af, er nemlig ikke uden videre en alment indlysende åbenbaring af Gud - hvad der også ville gøre troen alment indlysende - men en åbenbaring i mennesket Jesus fra Nazareth som Kristus på korset og dermed en åbenbaring af Gud under sin modsætning, men altså netop af Gud som Gud. ${ }^{10}$ Den moderne enighed om, at Gud kun kan erkendes gennem åbenbaring, er derfor ikke udtryk for en tilfældig insisteren på åbenbaringsbegrebets radikalitet i modsætning til almindelig erkendelse, men tværtimod udtryk for det modsatte forstået sådan, at det er udtryk for, hvor almindeligt og tvetydigt Gud giver sig til kende i modsætning til, hvis Gud havde åbenbaret sig ekstraordinært. Tværtimod. Netop fordi Gud åbenbarer sig på en måde, der så indlysende ikke ligner en åbenbaring, må radikaliteten fastholdes. Dette komplicerer spørgsmålet, om åbenbaring så selv radikalt bør forbeholdes selve "Ordet" eller selve begrebet "Kristus", for i begrebet forsvinder den konkrete radikalitet. Derfor synes det radikale ved åbenbaringen snarere at være selve det konkret dialektiske, og således støder vi på en anden version af det aspekt af problemstillingen, som jeg introducerede som et indviklet teologisk forhold mellem det egne og det fremmede, nemlig som et dialektisk forhold mellem det erkendte og det skjulte. ${ }^{11}$ Den moderne dogmatik kan hverken tage udgangspunkt i den usynlige eller den synlige Gud, og hverken i Jesus på korset eller den opstandne Kristus, men står med den udfordring at begribe - eller lade være - den dialektiske sammenhæng derimellem, der selv er blevet det dogmatiske udgangspunkt, og som den selv udtrykker konkret.

10. Danz henviser til Luther og forklarer: "Gott handelt, wie am Kreuz Christi sichtbar wird, unter dem Gegenteil verborgen. Damit verkehren sich allerdings im Lichte des Kreuzes Christi alle Dinge in ihr Gegenteil. Die Handlungen des Menschen mögen äusserlich gut erscheinen, sie sind jedoch innerlich schlecht und das Handeln Gottes mag äusserlich schlecht erscheinen, es ist jedoch innerlich gut [...] Sowohl beim göttlichen als auch beim menschlichen Handeln sind eine innere und eine äussere Dimension zu unterscheiden, die einer Dialektik von Sein und Schein unterliegen" (Danz 2010, 46).

11. Som Leonhardt siger om den moderne lutherske teologi: "Sie stigmatisiert die natürliche Gotteserkenntniss des Menschen als Resultat seiner sündhaften Abwendung vom wahren Gott. Anderseits wurde [...] daran festgehalten, dass es sich bei der durch der Sünde pervertierten natürlichen Gotteserkenntnis des Menschen doch um die Perversion einer Selbstbekündigung Gottes handelt" (Leonhardt 2001, 86). Derfor kan det menneske, for hvem sandheden i Kristusåbenbaringen er modtaget, ikke betragte sin naturlige gudserkendelse som synd, selv om den erfares som sådan (Leonhardt 2001, 86). 
Identificerer vi i den forbindelse åbenbaringen som Kristus og Kristus som åbenbaring, fordi vi vil afhjælpe det erkendelsesproblem, som det dialektiske åbenbaringsbegreb fører med sig, så reproduceres problemet som spørgsmål om, hvorvidt eller hvordan Kristus konkret kan udfoldes alment, f.eks. skabelsesteologisk eller universaleskatologisk. Udfordringen forbliver: Hvori består det alment erkendelige i den kristne åbenbaring, der samlet set netop er udmærket ved at være alt andet end almen? Så snart åbenbaringens almene karakter understreges og abstraheres fra sin konkrete sammenhæng, er den ikke længere åbenbaring. Dette problem undgås ikke med en skabelsesteologisk udfoldelse af åbenbaringen i Kristus, for den Kristus, som man dermed trækker ud af eller projekterer ind i skabelsen, f.eks. gennem forestillinger om universel inkarnation eller opstandelse, bliver også et abstrakt begreb for den Gud, som det reformatoriske åbenbaringsbegreb udfordrer, idet det lader modsætningerne i gudsbegrebet etablere sig som modsætninger indenfor åbenbaringsbegrebet og den menneskelige erkendelse. Åbenbaring drejer sig derfor ikke om en progression i erkendelse fra det abstrakte og almene - det være sig historie, fornuft eller natur - til det konkrete eller egne og omvendt heller ikke om en bevægelse fra egen erkendelse til universalviden. Tværtimod udfordrer det reformatoriske åbenbaringsbegreb langt mere radikalt vores erkendelses udgangspunkt, idet det tematiserer forskelle og modsætninger inden for åbenbaringsbegrebet selv og således peger på erkendelsens dialektiske karakter og modsætningsfyldte betingelser.

Så på samme tid, som der hersker udbredt enighed om åbenbaringens radikalitet, er det også blevet et hovedspørgsmål, hvorvidt erkendelsen uden for åbenbaringen og uden for Kristus lader sig anerkende som udtryk for andet eller mere end selvudlægning og selvretfærdiggørelse. Vel at mærke ikke, fordi denne opfattelse, der følger om enigheden om åbenbaringens radikalitet, er bragt i tvivl, men snarere fordi den fremtræder for indlysende - forstået sådan, at den fremstår fremmedgjort eller adskilt fra åbenbaringens almindelighed. Åbenbaringens radikalitet afspejler en dialektik, men denne er efterhånden blevet selvfølgeliggjort som optaget i åbenbaringsbegrebet selv og trænger følgelig til at blive af-selvfølgelig-gjort. I denne sammenhæng kunne behovet aktualiseres som et spørgsmål om, hvorvidt en given naturalistisk selvforståelse kan betragtes som udtryk for Guds retfærdiggørende udlægning af mennesket? Hvad betyder det dialektiske forhold mellem erfaring og begreb, enhed og modsætning, synligt og usynlig, som åbenbaringstemaet henleder vores opmærksomhed på i den sammenhæng? Læg mærke til, at den aktuelle teologiske uenighed om mulige svar på dette i vidt omfang kan tolkes som udtryk for 
en anerkendelse af den fælles reformatoriske åbenbaringsteologiske problemstilling.

\section{Troens primat?}

Forholdet mellem forskellige former for erkendelse og selvforståelse er netop hovedsagen $\mathrm{i}$ det tema, som ved siden af diskussionen om teologi og åbenbaring udgør den tredje oplagte indgang til forholdet mellem naturalisme og kristendom, nemlig temaet tro og herunder spørgsmålet om troens fornuft. ${ }^{12}$ Det dogmatiske udgangspunkt er, at Guds åbenbaring i Jesus Kristus kun erfares i tro, som man omvendt kan forstå som selve denne antagelse af åbenbaringen. ${ }^{13}$ Men hvad vil det sige at antage eller modtage åbenbaringen af Gud i Jesus Kristus? Hvilken form for forståelse er dette udtryk for? I hvilken forstand kan dette betragtes som fornuftigt?

Tilsvarende det moderne åbenbaringsbegreb kan den moderne reformatoriske forståelse af troen som tillid også forstås dialektisk. Det reformatoriske trosbegreb indebærer ganske vist en afvisning af den klassiske distinktion mellem troen som indhold og akt, og peger på troen som personlig fuldbyrdelse frem for som udtryk for en mangelfuld form for viden. Men denne vægt på den personlige fuldbyrdelse skal ikke ses som modsætning til troen som viden, men kan betragtes som udtryk for en problematisering og radikalisering af forholdet mellem tro og viden. Det vil sige som en understregning af, at troen er en personligt erfaret formidling af troens forskellige aspekter af egenhed og fremmedhed, aktivitet og passivitet. Derfor indeholder

12. Se Danz (2010, 31 ff.), Leonhardt (2001, 89 ff.) og Korsch (2000, 9ff.)

13. Leonhardt forstår troen som "menschliche Entsprechung zu göttlichen Offenbarung" (Leonhardt 2001, 89). Danz beskriver den reformatoriske opfattelse mere udførligt som "das unableitbare Geschehen des Sich-Verstehens des Menschen in der Gebrochenheit allen seines Tuns und zugleich da Vertrauen auf das göttliche Vergebungswort" (Danz 2010, 34). Korsch skriver "Glaube ist die am Ort meines Lebens vorhandene Gewissheit, dass aufgrund meines Daseins im Gottesverhältnis ein unverbrüchliches Ineinander von Selbstverhältnis und Weltverhältnis besteht und dass ich als Mensch mein Leben genau in diesem Zusammenhang der drei Vethältnisses gut und richtig führen kann" (Korsch 2000, 17-18). På den ene side er forskellen på disse beskrivelser påfaldende. På den anden side udtrykker de samlet set en tiltagende dialektisk spænding: Tro som svar - i betydningen tiltro - på Guds åbenbaring (Leonhardt), tro som gudsforanlediget tiltro til Guds tilgivelse i lyset af egen erfaring (Danz) og til sidst (Korsch) tro som vished om selvforhold og verdensforholdet sammenflettede ubrydelighed i gudsforholdet og mulighed for at leve dette forhold trods erfaringen af adskillelse. Tro er dermed ikke bare vished om tilgivelse af synd, men vished om, at visheden selv er udtryk for denne tilgivelse. 
den radikaliserede tro et særligt udpræget regnskabskrav. ${ }^{14}$ Fremfor at betragte den reformatoriske afvisning af distinktionen som udtryk for en afskaffelse af det fremmede og almene aspekt ved troen, kan man betragte den som en insisteren på den personligt erfarede formidling af aspekter. ${ }^{15}$ Den massive efterdialektiske modsigelse af troen som viden og dermed af troens fornuftighed og universalitet, kan altså betragtes som følge af en skærpet bevidsthed om troen som en særlig form for almindelig bevidsthed og erkendelse og på den baggrund betragtes som udtryk for et øget krav om godtgørelse af troens fornuftighed. ${ }^{16}$

14. Som Leonhardt skriver: "Weil der Glaube verstanden wird als unmittelbare Beziehung des Menschen zu einem personalen Gegenüber, als ein unbedingtes SichVerlassen auf Gott, kan sich der Mensch weder durch die Kirche noch durch irgendeine andrere Instanz vertreten lassen [...]. So ist letztlich jeder einzelne Christ selbst über seinen Glauben in vollem Umfang rechenschaftspflichtig." (Leonhardt 2001, 91ff., 95). Netop fordi troen er umiddelbar tillid, er mennesket fuld forpligtet på at aflægge regnskab for den. Danz forklarer med andre ord, hvorfor den reformatoriske insisteren på troen som umiddelbar personlig formidling ikke modsiger fornuften, men virkeliggør den sande fornuft: "Allein im individuellen Glaubensvolzug kommt es zum Übergang vom Zorn zur Barmherzigkeit. Insofern kan gesagt werden, dass im Glauben [...] nich nur der Mensch zu sich selbst kommt, sondern auch Gott sich erst als der verwirklicht, der er ist" (Danz 2010, 34). Dermed udtrykker Danz bedre end Leonhardt, at denne tro netop ikke skal forstås som rent indre modtagelse af Guds ydre åbenbaring, men betragtes som selv integreret i den og formidler af den. Hvordan troens personlige formidling skal forstås, og hvorvidt den er umiddelbar eller selv formidlet, er en omfattende diskussion, som Danz selv bl.a. har ført med Gunther Wenz i forbindelse med hans og Wolfhart Pannenbergs fortolkning af Paul Tillich. Se evt. Johanne Stubbe Teglbjærg, Krop og håb. En kritisk tolkning af nyere eskatologi under inddragelse af kropsfenomenologien (København: Det Teologiske Fakultet 2008), 208.

15. Leonhardt betragter på den ene side den reformatoriske understregning af den personlige tillidstro som et forsøg på at udtrykke en tillid, der er rystet, men ser den på den anden side også som udtryk for erfaringer af Guds trofasthed, og hævder, at når troen af Luther lod sig forstå som personlig fuldbyrdelse, så lod dette sig kun gøre, fordi fuldbyrdelsen, når alt kom til alt, stadigt havde trosindholdet som sin forudsætning (Leonhardt 2010, 90). Tillidstroen afspejler en særlig personlig sammenhæng mellem vished og uvished. Indenfor troens personlige regnskab har troens indhold således også i den efterreformatoriske teologi ikke kun en negativ, men en begrænset positiv betydning (Leonhardt 2001, 96). Se også Danz, der er mere radikal (Danz 2010, 40).

16. Danz omtaler den "massiven Bestreitung der Vernünftigkeit des christlichen Glaubens im neuzeitlichen Denken” og hævder, at troen derfor selv er blevet et eksplicit tema for fornuften (Danz 2010, 89). I sin yderste konsekvens beror dette dog på en underkendelse af troens egen fornuftighed og er, mener han, for så vidt misforstået. Danz betragter således troens ydre og indre fornuft som den samme og beskriver den tilsvarende som helt almindelig refleksion: "In dieser mit dem Glauben als einem Sich-Verstehen des Menschen verbundenen Endlichkeitsreflexion liegt das beschlossen, was man die Vernunft des Glaubens genannt hat. Es liegt auf der Hand, dass die Vernunft des Glaubens wenig mit der Frage zu tun haben kann, 
Den reformatoriske understregning af, at tro skal forstås som et personligt tillidsforhold og dermed udgør et tema for subjektivitetstænkningen, er altså ikke en afvisning af, at troen angår andet end subjektiviteten, men derimod en understregning af dette og af, at subjektiviteten således angår andet end sig selv. Det er netop, fordi menneskets egen tro grundlæggende angår andet end mennesket selv, at den overhovedet bliver et eksplicit tema, og netop fordi troen udtrykker en dybere passivitet - udtrykt med ord som uafledelig, ubetinget, umiddelbar - at den i den moderne teologi udtrykkes som en særlig personlig fuldbyrdelse. Tilsvarende er det netop som mangel på forståelse og tvivl, at den udtrykker sig som vished. Når man derfor kun yderst sjældent møder efterdialektisk udfordring af antagelsen af troens primat, så er det altså netop under forudsætning af, at dette primat faktisk ikke uden videre erfares eller reflekteres. Troens primat, kan man derimod sige, erfares så indlysende problematisk, at det er blevet dogmatisk selvfølgeligt at forsvare dette. ${ }^{17}$ Derfor kan man i forlængelse af den efterdialektiske undersøgelse af teologiens eksklusivitet og åbenbaringsbegrebets radikalitet også pege på nødvendigheden af at konkretisere troens primat med udgangspunkt $i$ undersøgelser af den menneskelige erkendelses almene endelighed og konkrete usikkerhed og negativitet, som det sker dogmatisk i skabelseslære og syndslære.

Samlet set åbner alt dette for muligheden af at betragte en eksklusiv, radikal og primær dogmatisk modstand mod rationalisme og naturalisme som udtryk for en indre dogmatisk anerkendelse af relevansen af disse tilgange - altså ikke blot betragte disse andre tilgange til tilværelsen som udtryk for ydre kristne forhold, men som relateret til en indre dogmatisk og kristen konstitutions- og erkendelsesproblematik, der angår forholdet mellem troens selvforståelse og begrundelse i forholdet mellem selv, den anden og Gud. Lad os derfor se

wie die als übernatürliche gengenstände verstandenen Inhalte des Glaubens mit der theoretischen Vernunft zusammenstimmen können” (Danz 2010, 42).

17. Tilsvarende personlige, dialektiske struktur kommer også til udtryk i spørgsmålet om bibelfortolkning og autoritet som en fjerde mulig indgang til afklaringen af forholdet mellem naturalisme og kristendom. Troen støtter sig både som viden og som tillid til Bibelen som en givet, ydre og kritisk autoritet, men i takt med den moderne insisteren på personlig vished (fremfor ydre autoritet og erkendelse) som nøgle til den, flyttes autoriteten i tiltagende grad fra skriftens form og indhold til dens sag. Jo mere tvivl om skriftens mangfoldige indhold, jo større klarhed om dens enestående sag, evangeliet om Jesus Kristus. Jo mere menneskelig skriften fremstår, jo mere entydig synes dens sag og midte at være blevet hævdet. Se også Danz, der beskriver, hvordan der dermed lægges pres først på trosbegrebet og dernæst på åbenbaringsbegrebet, idet disse skal udtrykke eller tage højde for den passive troskonstitution, som skriften ikke længere kan være forklaring på eller anledning til (Danz 2010, 47ff.). 
nærmere på den ambivalens, der knytter sig særligt til den moderne tros selvforståelse og det naturalistiske begreb om fornuft gennem et blik på den konkrete historiske teologiske sammenhæng, som begreberne "naturalisme" og "kristendom" er blevet til i.

\section{Begreberne: Tilblivelse og fremtrædelse}

Fælles for de forskellige aktuelle definitioner af begrebet naturalisme er, at de indebærer et bud på, hvad vi skal forstå ved natur og dermed udgør et indlæg i en bredere diskussion om menneskets konstitution og erkendelse. ${ }^{18}$ Naturalisme er et begreb, der siger noget om vores "natur", og noget om, hvordan vi kan erkende den, nemlig "gennem naturen" og det vil sige ikke "overnaturligt". ${ }^{19}$ Således kan man sige,

18. Begrebet natur kan anvendes som væsensbegreb (hvor det naturlige er det væsentlige, essentielle eller ideale), som komplimentær- eller kontrastbegreb (overfor kultur) eller som universalbegreb (der betegner det værende). Se Rosenau (Hartmut Rosenau,"Natur" i Theologische Realenzyklopädie, 24, (Berlin: De Gruyter 1994), 98-107 (98-99). Tilsvarende hersker der ikke enighed om den mere nøjagtige betydning af begrebet "naturalisme" og derfor er der også uenighed om den forståelse og forbindelse af forestillingen om natur og erkendelse, som begrebet selv udtrykker en opfattelse af. Når begrebet "naturalisme" optræder isoleret, er det ikke på forhånd til at vide, om det henviser til naturalisme forstået som en streng naturvidenskabeligt defineret opfattelse af tilværelsen eller til mere liberal filosofisk åben opfattelse, og ikke klart, hvorvidt dette perspektiv overhovedet forstår sig selv som perspektiv - dvs. en metode - eller som en neutral forudsætning for perspektiver og altså som ontologi. Som Troels Engberg-Pedersen og Niels Henrik Gregersen forklarer: "naturalism comes in a bewildering variety of stripes, each with its own distinctive commitment", hvorfor der er tale om en "vagueness of the term" (Troels Engberg-Pedersen og Niels Henrik Gregersen, "Introduction" i Essays in Naturalism \& Christian Semantics, red. Troels Engberg-Pedersen og Niels Henrik Gregersen (København: Det Teologiske Fakultet 2010), 12.) Under henvisning til Roy Wood Sellars antager de derfor, at den almindelig udbredte naturalisme "is of very vague and general sort, capable of covering an immense diversity of opinion" (EngbergPedersen og Gregersen 2010, 12-13).

19. Engberg-Pedersen og Gregersen beskriver den vage naturalisme som bestemt ved tre forhold, nemlig (1) en påstand om, at filosofien ikke er den grundlæggende videnskab, (2) en påstand om, at det, der eksisterer, beror på materielle entiteter af fysisk natur samt (3) en modstand mod supernaturalisme (Engberg-Pedersen og Gregersen 2010, 13). Ifølge Mario De Caro og David Macarthur er den mest almindelige definition på naturalisme afvisningen af "supernatural entities", hvilket de udlægger som udtryk for enten en benægtelse af Gud eller af en cartesiansk dualisme, hvis betydning for naturalismebegrebet de afskriver, idet de skriver "it is hard to see how this idea of the supernatural can help to provide a satisfactory understanding of contemporary scientific naturalism" (Mario De Caro og David Macarthur, "Introduction: The Nature of Naturalism" i Naturalism in Question, red. Mario De Caro og David Macarthur (Cambridge: Harvard University Press 2004), 1-17 (2-3)). Samtidens videnskabelige naturalisme forstår de følgelig som 
at jo stærkere "naturalisme" defineres som et modbegreb, jo mere tyder det på, at begrebet om det overnaturlige er relevant for forståelsen af naturalisme. Begrebet om det overnaturlige udgør måske en næsten privilegeret tilgang til naturalismen. Dette lægger op til en tilgang med blik for det, som ligger uden for naturalismens felt og metode.

Ifølge Christian Danz har det moderne begreb "naturalisme" sin tidlige oprindelse i den reformatoriske radikalisering af spørgsmålet om den menneskelige erkendelses konstitution og betingelser og udviklede sig for alvor som følge af det 17. og 18. århundredes teologiske og filosofiske diskussion om skriftfortolkning og åbenbaring. ${ }^{20}$ Det reformatoriske krav om en tolkning af Bibelen som personlig indlysende - og i den forstand fornuftig - betød nemlig, at åbenbaringen nu ikke kunne hævdes som en autoritet, der var givet uden om menneskets egen dømmekraft, som på den anden side så også kom under særligt pres. Naturalismens modstykke var derfor ikke uden videre den veludviklede supernaturalisme, som argumenterede for begrænsningerne i menneskets dømmekraft og erkendelse, og heller ikke den tidlige rationalisme, der tværtimod udgjorde en fælles forudsætning for både naturalisme og supernaturalisme.

Begrebet supernaturalisme kan således også betragtes dogmatisk som et særligt moderne begreb, nemlig et begreb for den protestantiske teologi, der senere - ved overgangen fra det 18. til det 19. århundrede - eksplicit modsagde tidens nye teologiske naturalisme. ${ }^{21}$ I modsætning til den fornuftige - forstået som den egne aktuelt tilegnede og derfor primært kritiske udlægning af åbenbaringen -

en forpligtelse på en videnskabelig forståelse af naturen og en tilsvarende videnskabelig tilgang til den. Dette svarer til Christian Danz's udlægning af naturalisme som et begreb for en særlig fortolkning af mennesket i dets samlede sociokulturelle situation, der er kendetegnet ved at være begrænset til naturkategorier - altså en fortolkning, der er begrænset til en særlig "natur"-kategori og dermed udgør "a critical counter-position to the concept of revelation in the theological and ecclesial tradition" (Danz 2013, 1) (Christian Danz, "Naturalism. II. Philosophy of Religion”. Brill Online 2013. Det Kongelige Bibliotek: http://referenceworks.brillonline.com.ep.fjernadgang.kb.dk/entries/religion-past-and-present/naturalismCOM_024034?s.num=0 \&s.f.s2_parent=s.f.book.religion-past-and-present \&s. $\mathrm{q}=$ naturalism $)$.

20. Se Danz $(2013,1)$. Udgangs- og omdrejningspunktet i striden mellem naturalisme og supernaturalisme var ifølge Danz ikke primært en strid om naturen, men om erkendelsen og om "the origin, mediation, and appropriation of the Christian cognizance of truth", hvilket på den anden side ikke kan adskilles fra spørgsmålet om naturen (Danz 2013, 1).

21. Dette betyder ikke, at begrebet ikke optræder før, men at det får sin særlige betydning i denne moderne sammenhæng. Se Joachim Weinhardt, "Supranaturalismus” i Theologische Realenzyklopädie, Vol 32, (Berlin: De Gruyter 2001), 467$472(467-468)$. 
argumenterede supernaturalisterne for en historisk åbenbaring med en konstruktiv udfoldelsesmulighed. De fastholdt, at der er et indhold i åbenbaringen, der ikke er tilgængeligt for menneskets egne ressourcer alene, men formidles gennem mirakler og profeti og under inspiration. Supernaturalisterne tog altså afstand fra en reduktion af den overleverede åbenbaring til en egen og kritisk fornuftserkendelse. De forsøgte under anerkendelse af fornuftens betydning at flytte på grænserne for opfattelsen af fornuften og videreførte dermed den reformatoriske indsigt $\mathrm{i}$ tillidstroens egen dialektik som en spænding mellem natur og overnatur inden for fornuftbegrebet selv. ${ }^{22}$ I denne diskussion om erkendelsens fornuftighed, blev supernaturalismen fortaler for en åbenbaringsbaseret positiv religion, en "kristendom", mens den tidlige naturalisme forsvarede "a natural religion to which universality and necessity are ascribed, self-evident to every individual by means of reason" (Danz 2013, 1). Dermed udviklede det moderne teologiske åbenbarings- og trosbegreb sig mod sin egen dialektiske oprindelse i tiltagende modsætning til et naturalistisk fornuftbegreb, mens dette omvendt afskrev sin tilblivelsessammenhæng og definerede sig i modsætning til teologien overhovedet. ${ }^{23}$

Den moderne adskillelse af natur og overnatur hører således hjemme i samme selvforståelses- og erkendelsesproblematik, som den efterdialektiske begrebssammenhæng introducerede som indgang til en

22. Som Weinhardt understreger, så delte den tidlige rationalisme og supernaturalismen de samme forudsætninger, idet de forstod tro som sandheden af et bestemt læreindhold og antog den naturlige religions indhold for sandt, fordi den kunne udledes af den praktiske fornuft. Forholdet mellem rationalisme og supernaturalisme udspillede sig derfor primært som en diskussion af Kants kritik af den teologiske metafysik (Weinhardt 2001, 468-471). Weinhard skelner i den forbindelse mellem det overnaturlige og unaturlige i betydningen ufornuftige eller irrationelle og giver eksempler på, at det overnaturlige $i k k e$ var ensbetydende med det irrationelle. Selv de strengeste forsvar for supernaturalismen var ikke udtryk for "unvernünftiger Irrationalismus": "Fest stehe, dass die wahre Offenbarung überhaupt nichts der Vernunft Widersprechendes enthalten könne, weil der Offenbarer selbst die unendliche Vernunft sei" (Weinhardt 2001, 469). "Wie die Darstellung zeigt, war der Supranaturalismus nicht rein offenbarungspositivistisch bestimmt. Er versuchte vielmehr, die vom Gegner eingenommene Position der Vernunft vor dem Forum der Wahren Vernunft - die mit der Offenbarung in Einklang stand und von dieser her entworfen wurde - als defizitär nachzuweisen." (Weinhardt 2001, 470). Bemærk, at dette drejer sig om den strengeste supernaturalisme og ikke om de forskellige blandingsformer mellem supernaturalisme og rationalisme, der også fandtes.

23. Danz beskriver begrebernes tidlige tilblivelsessammenhæng som transformationen af en spænding mellem den bibelsk-kristen tradition og den filosofiske metafysik, der løber gennem hele kristendommen historie: "Although the full impact of the antithesis of naturalism and supernaturalism was not felt until the Enlightenment, through the entire history of Christianity there ran a tension which resulted from the changing positions of the biblical-Christian tradition with regard to metaphysics." (Danz 2013, 1) 
dogmatisk afklaring af forholdet mellem naturalisme og kristendom. For så vidt kan dogmatikken ikke ophæve den moderne modsætning mellem naturalisme og kristendom, ligeså lidt som den kan omgås denne modsætning, som om den skulle være absolut. Dogmatikken udfordrer i stedet ethvert forsøg på at begribe den menneskelige erkendelse som et rent enten-eller, dvs. som en erkendelse, der udspringer af et kristent begreb eller som en kristen erfaring, der fører til et begreb. $^{24}$

\section{Kritik og konstruktion}

Dermed er vi allerede midt inde i en teologisk diskussion, som ikke på forhånd er defineret ved et vilkårligt begreb om kristendom forstået ud fra et abstrakt begreb om positiv religion eller defineret tilsvarende vilkårligt ved en afsked med selve kristendomsbegrebet overhovedet. Begrebet kristendom er ligeså problematisk som begrebet naturalisme, fordi det går ud fra en kategori, nemlig "det kristne", der positivt forstået - altså betragtet som manifestation - er ligeså uklart som kategorien natur, idet manifestationerne er så mangfoldige, at spørgsmålet om deres enhed og identitet bliver akut. I den dogmatiske bearbejdning af dette spørgsmål er der, som jeg har forsøgt at vise, ikke et fundament at falde tilbage på, men en konkret åben - dialektisk - refleksionssammenhæng.

I stedet drejer den teologiske diskussion sig altså om, hvad vi bør forstå ved åbenbaring og tro, erkendelse og fornuft. Det er gennem en udfoldelse af disse begreber under hensyn til deres dialektiske tilblivelseshistorie og paradoksale fremtrædelsesform, at man kan nærme sig en dogmatisk afklaring af forholdet mellem naturalisme og kristendom. Denne tilnærmelse må så som udgangspunkt tage højde for, at åbenbaring og tro efter det reformatoriske fokus på troen som personlig vished, den tidlige rationalismens appel til erkendelsens faktiske sikkerhed og kriticismens kritik af den teoretiske fornuft, udfolder sig i spørgsmålet om den personlige fornuft og dens konkrete og almene forudsætninger. Åbenbaring og tro er ikke primært et spørgsmål om abstraktion, spekulation og teori. Åbenbaring og tro drejer

24. Danz konstaterer i den forbindelse: "The antithesis of supranaturalism and naturalism/Rationalism in the late theology of the Enlightenment not only represent a continuation of earlier positions, but is itself merely a variation of an antithesis that runs through the entire history of theology [...] This historical antithesis reflects a problem of fundamental theology that extends beyond the positions emerging during the history of theology, and cannot be adequately grasped by the abstract alternative naturalism/supranaturalism." (Danz 2013, 1). 
sig dermed ikke bare om vores erkendelse af os selv og af tilværelsen, men om hvad der allerede konstituerer denne som netop vores erkendelse. Alene af den grund lader "naturalisme og kristendom" sig ikke adressere dogmatisk som en ren teoretisk og konstruktiv opgave, dvs. som begrebsudfoldelse, men udgør en praktisk og kritisk udfordring, der går ud på at tage det op, som vi allerede tror, at vi forstår. Vi kan ikke komme bag om erfaringen af en adskillelse af fornuftens teoretiske og praktiske perspektiv og dermed ikke bag om det erfaringsbetingelsesproblem, som vi dermed faktisk har - og selv bliver udtryk for. Sådan set er det derfor, at "kristendommen" ikke kan komme af med "naturalismen". Dertil kommer så, at åbenbarings- og trosbegrebet ikke kun er udfordret negativt af empirismens argumentation for sanseerfaringernes vishedskonstituerende karakter, men tværtimod også modtager deres betydning fra begreber fra erfaringen. Så selvom teorien og spekulationen ofte er blevet hævdet afskaffet af den tiltagende moderne empirisme og monisme, så kan naturalismen ikke komme uden om sit filosofiske eller teologiske grundlag - forstået sådan, at jo mere snævert naturalistisk dette defineres, jo mere afhængigt gør det sig af særlige filosofiske forudsætninger. Den dogmatiske betydning af dette er, at "naturalisme og kristendom" heller ikke kan være et rent praktisk og kritisk foretagende, men som praktisk og kritisk også altid er teoretisk og konstruktivt.

Dermed peger jeg selvfølgelig ikke på noget nyt, men forsøger at understrege og opholde mig ved - frem for at forsøge at eliminere - den nærværende spænding mellem det praktiske og teoretiske samt kritiske og konstruktive tilgang for på denne baggrund at overveje, hvad dette spændingsfyldte udgangspunkt faktisk kan betyde for "naturalisme og kristendom". Det indebærer naturligvis ikke en forestilling om et neutralt tredje standpunkt midt mellem de to, dvs. et neutralt standpunkt, der forener dualismens kritik og monismens konstruktion, men udfolder dogmatikken som en konkret spændingsfuld og tvetydig identifikation af kristen erfaring og det kristne. Set således er dogmatikkens opgave at afdække kritisk og konstruktivt fremvise den kristne meningssammenhæng, der ikke lader sig begribe under entydige modsætningspar som natur og overnatur, men højst lader sig identificere under særlige vilkår. ${ }^{25}$ Spørgsmålet er naturligvis, hvad denne i sig selv kritiske tilgang til forholdet mellem naturalisme og kristendom nu betyder mere konstruktivt.

25. Denne sammenhæng har jeg forsøgt at beskrive som en trinitarisk kontinuitet, se Johanne Stubbe Teglbjærg, "Ambiguity, the Trinity and Naturalism: From the Methodology of Pannenberg to the phenomenology of Merleau-Ponty" i Theology and Science 10, 1, (2012), 19-38.) 


\section{3. "Naturalisme og kristendom" mellem Gud, selv og synd}

For at få greb om dette må vi frem til den aktuelle dogmatiske sammenhæng igen og til den konkrete komplikation, der er på spil i forholdet mellem naturalisme og kristendom og problemstillingen tro og fornuft. Det reformatoriske og rationalistiske understregning af, at vished er egen vished, betyder, at det personlige og aktive træder frem som et kendetegn ved det kristne, men på den anden side også viser sig som dette, der kompromitterer eller ligefrem ødelægger det. ${ }^{26}$ Det personlige er nemlig også kendetegnet ved erfaringen af uvished og falsk vished. Derfor er det personlige spændingsfuldt og faktisk tvetydigt. Dette forsøger de efter-dialektiske teologer at holde fast i og således opholde sig ved teologien, åbenbaringen og troen, som forskellige positive udtryk for denne spænding.

På den ene side er troen udtryk for, at mennesket bliver det, det er (altså sig selv), men på den anden side er troen også udtryk for, at mennesket bliver noget andet end det faktisk er (nemlig falskt eller overdrevent sig selv). Synden er ifølge den efter-dialektiske opfattelse menneskets egen fordrejning mod sig selv, hvorved mennesket tror, at det nærmer sig selv og bliver sig selv, men faktisk bliver fremmed for sig selv. Ligesom visheden $-\mathrm{i}$ kraft af at formidle forskellige aspekter og relationer - er en personlig fuldbyrdelse, således er synden det også. Synden er også en personlig fuldbyrdelse af den formidling eller det forhold, som mennesket selv er. At også synden er den faktiske fuldbyrdelse af det personlige, gør selve det personlige tvivlsomt som udgangspunkt. ${ }^{27}$ Den indebærer, at kristen identitet og normativi-

26. Der er to elementære forskellige dogmatiske forhold på spil her. For det første dette, at mennesket ikke er selvkonstituerende, men skylder sig et fremmed ophav, dvs. er skabt, og for det andet dette, at menneskets faktiske forhold til dette ophav er ødelæggende. Mens Korsch tematiserer det første som et spørgsmål om menneskets forhold til det fremmede i sin ydre og indre konstitution, bliver det andet udtryk for en radikalitet i denne fremmedhed, der er ødelæggende. Mennesket er ikke bare unddraget for sig selv - mere fremmed for sig selv end for noget andet - men ligefrem udleveret negativt til sin egen radikale fremmedhed, således at det ikke ved hjælp af sig selv, men kun ved en omvej over Gud som en dybere dialektisk sammenhæng mellem det fremmede og det egne kan leve gennem sin radikale ikke-identitet (Dietrich Korsch, Dialektische Theologie nach Karl Barth, (Tübingen: Mohr Siebeck 1996), 20-22).

27. Som Pannenberg siger, er der tale om, at menneskets "væsensnatur" er skabt god, mens dets faktiske "natur" i kraft af sine "individuelle naturbetingelser" er syndigt fra fødsel af (Wolfhart Pannenberg, "Sünde, Freiheit, Identität”, Natur und Mensch - und die Zukunft der Schöpfung”, (Göttingen: Vandenhoeck \& Ruprecht 2000), 237). Det vil sige, at det er i den individuelle konstitution og dvs. i den individuelle almenhed - hvordan vi end skal forstå denne formidling af individualitet og almenhed - at syndens rod skal søges. Synd er, siger Pannenberg, en fordrejning i subjektiviteten, der lader denne fremstå i modsætning til sig selv, andre og Gud. 
tet ikke giver sig selv, men heller ikke gives uden sig selv, og denne negativitet fører således betragtet ikke kun væk fra troen, men også ind i den. Der er med andre ord ikke nogen vej til Gud uden om denne komplikation, uden om synd og død, selvom den vej ikke selv er synd og død. ${ }^{28}$ I erfaringen af synden ligger således både, det som kristendommen for en umiddelbar betragtning ikke deler med naturalismen, nemlig erfaringen af det egnes negativitet og erkendelsens radikale begrænsning, og det, som den, dogmatisk betragtet, deler med naturalismen, nemlig forestillingen om en reel begrænsning og faktisk afgrænsning. Derfor fremstår begrebet synd umiddelbart som en forskel mellem kristendom og naturalisme, mens troen og teologien, der reflekterer synden, også afslører en dybere sammenhæng mellem dem.

Både på grund af erfaringen og begrebet synd hænger der i dag en særlig tvetydighed ved den efter-dialektiske teologiopfattelses åbenbarings- og trosbegreb - ligesom ved dens brug af ordet "fornuft" - som den vel at mærke selv tematiserer i begge henseender. Man kan i dag ikke på forhånd vide, hvad en given dogmatisk antagelse af åbenbaringens "fornuft" betyder, og slet ikke vide, hvorvidt et sådant udtryk skal forstås som et udsagn om dens værdighed eller elendighed. Både troen og fornuften er i dag dogmatisk tvetydige og deres konkrete brug altid under mistanke. Begge begreber kan anskues som indbegrebet af personlig frihed og som indbegrebet af undertrykkelse. At min fornuft er min fornuft og min tro min tro, udmønter sig i praksis både positivt og negativt. ${ }^{29}$ Denne faktiske komplikation drejer sig

Subjektiviteten er ikke bestemt som modsætning, men fremstår faktisk både som forskel og i modsætning. Negativiteten drejer sig altså ikke om, at mennesket er forskelligt fra Gud, skabt, endeligt og i alle henseender begrænset, og kan derfor ikke omsættes til et spørgsmål om, hvordan mennesket er relateret til en uendelighed eller transcendens og til et spørgsmål om religion. Den drejer sig i stedet om, at den relation mellem immanens og transcendens, som mennesket selv er, kommer til udtryk som tro, der forvandler synd, og det vil sige som en særlig åben enhed af positivitet og negativitet.

28. Se f.eks. Leonhardt, der skriver om Luthers forsvar for en distinktion mellem bibelsk og filosofisk antropologi: "Die Theologie aber, die den ganzen Menschen im Blick hat, muss feststellen, dass die Sünde auch von der Vernunft vollständig Besitz ergriffen hat. Das Gottesverhältnis des Menschen ist daher so tief gestört, dass es keine Möglichkeit gibt, aus eigener Kraft einen Schritt auf Gott zuzugehen. Eine sachgemässe theologische Definition des Menschen darf sich deshalb nach Luther nicht an der Rationalität orientieren." (Leonhardt 2001, 179).

29. Den senmoderne dogmatiske diskussion om åbenbaring og tro udtrykker med al tydelighed selv denne ambivalens. Dialektiske og efter-dialektiske teologer henviser typisk til troens førstepersonsperspektiv som det perspektiv, der er afgørende for erkendelsens vished, mens de samtidig også hver især er dybt optaget af, at dette perspektiv ikke er selvkonstituerende eller selvretfærdiggørende, men tværtimod et problematisk perspektiv, fordi det både optræder som fremmed for sig selv og i 
ikke alene om den erfarede negativitet, som dogmatikken afdækker og udfolder, men om hvorvidt og hvordan den selv trods sin forpligtelse på den konkrete åbne dialektisk-paradoksale erfaring er udtryk for den. Det er dette tvetydige begreb om egen identitet, der gør dogmatikkens forhold til naturalismen vanskeligt at udrede. Den afslører det kristne som noget, der ikke fremtræder på trods af naturalismens fremmarch, eller i modsætning til den, men selv forudsætter den. Altså forudsætter den efter-dialektiske dogmatik selv den moderne naturalisme. Den er både en ambivalent betingelse og en erfaring.

Et dogmatisk perspektiv, der tager højde for dette, forudsætter anerkendelse af en særlig form for væren, der ikke kan forstås gennem andet end sig selv og i den forstand er personlig. I den dialektiske og efter-dialektiske teologi er lige præcis denne forestilling en afgørende forudsætning i antropologien, hvor den kompliceres, og i gudslæren, hvor denne komplikation udfoldes positivt. Gud giver sig således kun til kende ved åbenbaring, og Guds åbenbaring er selvåbenbaring. ${ }^{30}$ Dette er udtryk for en positiv forestilling i erkendelsesproblematikken og rationalitetsudfordringen, som teologien deler med naturalismen, selvom naturalismen i det omfang den afviser troserfaringen og syndserkendelsen som en personlig grænseerfaring, også afviser den radikale erkendelsesmæssige og antropologiske negativitetsproblematik, som teologien insisterer på og udfolder i alle dogmatikkens temaer. Dermed bliver det også endnu mere tydeligt, hvad det er, dogmatikken ikke deler med naturalismen. Det er nemlig ikke primært den overordnede negativitetsproblematik, altså synden, men snarere synderkendelsen og den paradoksale vished om dennes dialektiske forudsætninger. For lige præcis forestillingen om en radikal anden eller et radikalt fremmed, der begrænser mennesket og dets erkendelser, udtrykker naturalismen selv, idet den faktisk afgrænser sig overfor supernaturalismen. Derfor er det nærmere i syndserkendelsens anerkendelse af den eksistentielle dialektik og begrebsmæssige paradoksalitet i forholdet mellem det personlige og det negative

modsætning til sig selv og alle andre perspektiver, altså dualistisk, og dermed også skaber og bekræfter sin egen indre splid. Pannenberg er en af de efterdialektiske teologer, der har været hårdest i sin kritik af den dialektiske opfattelse af åbenbaring og forsøgt at integrere andre videnskabelige perspektiver - frem for alt historiske - i sin opfattelse af Guds åbenbaring som historie og tilsvarende fremhæve troens almene fornuft som et modtræk til en teologi, der efter hans opfattelse udialektisk har abstraheret åbenbaringen og troen. Se f.eks. Wenz (2005, 276). Eller se Teglbjærg for en nærmere undersøgelse af Tillichs, Moltmanns og Pannenbergs opfattelse af opstandelsesvished (Teglbjærg 2008, 155ff.).

30. Se f.eks. Wolfhart Pannenberg, "Offenbarung und 'Offenbarungen' im Zeugnis der Geschichte”, Natur und Mensch - und die Zukunft der Schöpfung, (Göttingen: Vandenhoeck \& Ruprecht 2000), 232ff. 
fremmede, at forskellen til naturalismen ligger. Denne dialektik og paradoksalitet synes fortrængt af de former for naturalisme, der ikke anerkender deres indre relation til supernaturalismen.

Udfordringen ved at udfolde forholdet mellem naturalisme og kristendom mere detaljeret dogmatisk er nu ikke blot, at dette så kun kan gøres indholdsmæssigt konkret gennem udfoldelse af de relevante temaer, men at dette foretagende selv er præget af en fortrængning tilsvarende naturalismen, nemlig af en overdreven insisteren på teologisk selvstændighed manifesteret aktuelt i forsvaret for teologisk eksklusivitet, åbenbaringens radikalitet og troens primat. Den efterdialektiske enighed om disse forhold fremstår således som en adskillelse af teologien fra den naturalistiske tilgang, og kun indirekte som en sammenhæng mellem det naturalistiske og supernaturalistiske perspektiv. Dermed befordrer dogmatikken direkte naturalismens løsrivelse og absolutering og bidrager tilsvarende til en forskydning af den almindelige forståelse af troen fra at være passiv til aktiv, fra frigjort til undertrykt og fra fornuftig til nærmest irrationel. Begrebet tro fungerer i dag - selv efter metafysikkens afsked, religionens genkomst og postmodernismens indtog - som et modbegreb til fornuft. Det kan være nærliggende at tolke denne udvikling som udtryk for, at den reformatoriske insisteren på den sande fornufts passivitet aldrig har slået igennem, men det kan også forholde sig modsat, således, at denne passivitet er slået igennem bare ikke som teologi, men som naturalisme og som en opfattelse af, at vi er underlagt naturen. Altså at vi er underlagt vores natur og den naturalistiske forståelse af os selv. For her er netop ingen aktuel dialektik - kun en fortrængt. ${ }^{31}$ Kun påstande om frihed og afhængighed, men ingen relation mellem de

31. Naturalismen kan derfor beskrives fænomenologisk som et monistisk modstykke til en rationalistisk, kriticistisk eller idealistisk dualisme, men bliver dog selv i takt med, at den tager afstand fra en opfattelse af fornuft som selvkonstituerende, selv indbegrebet af denne dualisme. I jo højere grad naturalismen holder fast i et strengt tredjepersons perspektiv, i jo højere grad bliver førstepersons perspektivet enten til en udfordring eller et implicit postulat. Jo strengere naturalismen definerer sig i modsætning til alt, hvad der ikke er "natur", jo mere afhængig bliver den af selvsamme "ikke naturlige" kategorier. Denne pointe er bl.a. blevet udfoldet detaljeret af Maurice Merleau-Ponty og Bernhard Waldenfels, der betragter naturalismen som et udtryk for en indre spænding i den menneskelige erkendelse. Naturalismen bliver således i sin strenge form ikke blot bud på en monistisk opfattelse af verden, men selv udtryk for en dualisme eller ligefrem supernaturalisme som Waldenfels forklarer: "Die personalistische Einstellung und mit ihr der Leib hat vielmehr der naturalistischen Einstellung und dem Körper gegenuber einen gewissen Vorrang. [...] Die personalistische Einstellung ist in der naturalistischen vorausgesetzt, denn Naturalisierung bedeutet, dass ich den eigenen oder den fremden leib oder einen kulturgegenstand als blosse Natur betrachte. Die blosse Naturbetrachtung ist ein Reduktionsprozess." (Bernhard Waldenfels, Das leibliche Selbst. Vorlesungen zur Phänomenologie des Leibes. Frankfurt am Main: Suhrkamp 2000, 252). 
to. Ingen formidling, spænding eller overgang mellem de to. Denne spænding og overgang bør, mener jeg, dogmatikken opholde sig længere ved, for det er gennem denne - erfarede - overgangsstruktur eller transformationsfigur, at naturalismens og kristendommens møde tematiseres, og deres positive forskelle træder frem.

\section{Mellem fanomenologi og hermeneutik}

Spørgsmålet er derfor, hvordan dogmatikken afsøger og udtrykker sin egen ambivalens, altså sin positive grund eller grænse, og dermed også tager højde for den aktuelle negativitet, der kendetegner den. Spørgsmålet kan stilles både hermeneutisk og fænomenologisk, men udgør også selv en udfordring både for rationalistiske former for hermeneutik og mere kropsligt orienterede fænomenologier. For hvordan kan man både tage højde for, at mennesket er indlejret i verden og en del af den og et perspektiv på den og adskilt fra den uden selv at optræde vilkårligt? Hvordan forstår den hermeneutiske tilgang sig som præget af det, der unddrager sig fortolkning? Hvad stiller en eksistentiel fænomenologi op med forholdet mellem mennesket og væren som et forhold, den selv udtrykker og deri viser sig allerede at være?

Disse spørgsmål, som den efter-dialektiske teologi deler med den kontinentale filosofi, rejser Maurice Merleau-Ponty i sidste del af sit forfatterskab, hvor hans tidlige fænomenologiske forsøg på at beskrive den menneskelige erkendelses forudsætninger som særlig fornuftig sanselighed fører ham til radikalt at udfordre beskrivelses- og fortolkningsforetagendet selv. ${ }^{32}$ For hvordan kan dette filosofiske foretagende komme til rette med sin grundlæggende passivitet? Når den hverken kan rodfæstes i verden eller uden for? Spørgsmålet drejer sig ifølge den sene Merleau-Ponty om, hvorledes vi kan - hvis vi altså kan

32. I sin sene ontologi forsøger Merleau-Ponty at afdække og udforske en konkret forbindelse mellem en positiv filosofisk tradition fra Descartes og Husserl og en negativ tradition fra Hegel, Marx, Kierkegaard, Nietzsche og Heidegger. Denne forbindelse betragter han som udtryk for en mutation i forholdet mellem menneske og væren, der har været på vej siden Hegel og melder sig særligt i poesi, musik, kunst. Som kulturelle symptomer på mutationen lægger disse fænomener op til en gentænkning af forholdet mellem menneske og væren, der tager sig selv alvorligt som udtryk for samme. Mauro Carbone udlægger udfordringen således "Philosophy has never spoken ... of the passivity of our activity' [...] Merleau-Ponty judges. For this reason, he intends to start from the idea of chiasm in order to 'elaborate an idea of philosophy' that ' cannot be total and active grasp, intellectual possession, since what there is to be grasped is a dispossesion' [...]" (Mauro Carbone, The Thinking of the Sensible. Merleau-Ponty's A-Philosophy. Evanston: Nothwestern University Press 2004, xiii-xvii). 
- tage højde for, at den menneskelige bevidsthed udspiller sig som en særlig begrænsning i forhold til verden, der ikke primært udgør en benægtelse af verden, men en åbning mod verden. Tager vi højde for dette befinder vi os hinsides, eller som Merleau-Ponty ville sige "under", det monistiske og det dualistiske perspektiv. Mauro Carbone beskriver i den forbindelse Merleau-Pontys ontologi som et forsøg på at udfolde subjektivitet som en aktivitets passivitet, hvor menneskets forhold til væren samtidigt er "a taking and a being taken", hvor "the hold is held, it is inscribed and inscribed in the same being that it takes hold of" (Carbone 2004, XIV). Denne subjektivitet udtrykker et forhold mellem mennesket og væren, der ikke kan begribes, fordi det består i en berøvelse - altså ikke bare fordi dette forhold som udgangspunkt ikke står til disposition - men fordi det unddrager sig simultant ved vores tilnærmelse. Det betyder, hævder Cabone, at "philosophy, instead of being, as it seemed before, a retrospective truth added on to experience, now shows itself as an experience that apprehends itself questioning its own initial truth", hvor det nye ikke er, at denne filosofi går kritisk frem, men at den forstår sig selv, idet den går kritisk frem. Filosofien er, siger han, studiet af en mening, der bliver til på stedet, hvis tavse forudsætning negeres og bedrages, når den formuleres (Carbone 2004, 26)..$^{33}$

De dogmatiske implikationer af dette er en opfordring til - med Mauro Carbones ord - at opholde sig ved sig selv som "crossed by the chiasm between activity and passivity" og dermed som et sted, hvor værens egen refleksivitet udspiller sig. Med dogmatikkens ord er det en opfordring til at erkende sig selv som det sted, hvor den korsfxstede Kristus opstår og synderen retfærdiggøres. Hvordan dette sted, denne krydsning af tid og rum og denne samtidighed skal beskrives, bør selvfølgelig diskuteres. Merleau-Ponty bruger selv begrebet "hyperdialektik" i forbindelse med mutationen af forholdet og begrebet "hyper-refleksion" i forbindelse med filosofien, der ikke er traditionel filosof, fordi den opgiver sig selv for, at verden kan sige det, som den i sin tavshed vil sige, og således ankommer som a-filosofi ved filosofiens grænser. Dette indebærer et afkald på kravet om en intellektuel besiddelse af "the Begriff" og omformer filosofiens dyd til en "letting-be", der hviler på sansningen som en "interrogative thought" (Carbone 2004, 42). Forholdet, spændingen og overgangen mellem aktivitet

33. Spørgsmålet bliver derfor, hvordan filosofien kan finde "a language of which he [i.e. the philosopher] would not be the organizer, words he would not assemble, that would combine through him by virtue of a natural intertwining of their meaning, through the occult trading of the metaphor - where what counts is no longer the manifest meaning of each word and of each image, but the lateral relations, the kinships that are implicated in their transfers and their exchanges" (Carbone 2004, 26). 
og passivitet er her ikke et "beyond", en "transcendens" eller et "hinsides", som filosofien skal begribe, men et "beneath", der udtrykker en udelt følelse, et oprindeligt ja, som af Merleau-Ponty også kaldes for den æstetiske verdens logos (Carbone 2004, 44). I modsætning til begribelsen og begrebet, der går fejl af sagens simultane unddragelseskarakter, så lægger dette "ja” op til en tilgang, der lytter og lader være eller lader stå til. For kun derigennem manifesteres den indre dialektik eller overgang, som vi ikke kan manifestere, men kun lade os manifestere af.

Følger vi denne tankegang, er forholdet mellem "naturalisme og kristendom" ikke spørgsmålet om, hvor lidt eller hvor meget naturalistisk fornuft den kristne tro udtrykker, men et spørgsmål om, hvad fornuft, erkendelse og identitet samlet betragtet overhovedet er. Det bliver således snarere et spørgsmål om, hvordan man forholder sig og kan forholde sig til dette, at den menneskelige identitet på samme tid konstituerer sig dialektisk monistisk og paradoksalt dualistisk, således at vi på den ene side ikke kan gribe identiteten, men på den anden side faktisk erfarer den. 